\title{
Districtwise wheat and rice yield predictions using meteorological variables in eastern Madhya Pradesh
}

\author{
A. K. GIRI, M. BHAN and K.K.AGRAWAL \\ College of Agricultural Engineering, JNKVV, Jabalpur 482004 Madhya Pradesh \\ E-mail:bhan.manish@gmail.com
}

\begin{abstract}
District wise rice and wheat yield prediction equations were developed for seven districts of eastern Madhya Pradesh using weakly weather data from 1980-2009. The coefficient of determination $\left(R^{2}\right)$ varied between $0.4-0.78$ for rice and $0.6-0.92$ for wheat in different districts. Model performance was evaluated with independent reported data for year 2010 and 2011. As the deviations for both the years were less than \pm 15 per cent, the models can be used for predicting the rice and wheat yields in Madhya Pradesh.
\end{abstract}

Key words : Wheat, rice, forecast grain yield, stepwise regression.

Madhya Pradesh is the leading producer of rice (Oryza sativa $\mathrm{L}$ ) and wheat (Triticum aestivum $\mathrm{L}$ ) however, their varieties are more susceptible to climatic stress (NPCC, 2007). Climate change affect their production due to rainfall variability and temperature stress thereby affecting their yield. In eastern Madhya Pradesh, wheat is a major rabi season crop while rice is grown during kharif season under rainfed condition. Change in intensity in solar radiation, temperature and distribution of rainfall provoke physiological reactions that affect crop growth and grain yield in rice (Yoshida and Parao, 1979). Therefore, a proper planning is needed to predict yield in advance as it will help in implementing and formulating of policies related to food procurement, distribution and import-export decisions.

In this study, regression equations were developed for predicting district wise wheat and rice yield in different districts of eastern Madhya Pradesh.

\section{MATERIALAND METHODS}

Seven districts (Balaghat, Jabalpur, Mandla, Narsinghpur, Seoni, Shahdol and Sidhi) of Madhya Pradesh (M.P.) were selected for developing district wise yield prediction equations for rice and wheat crops (Table 1). The daily weather data of the past 30 years $(1980-2009)$ of maximum and minimum temperatures, morning and afternoon relative humidity and rainfall were collected from Meteorological centre, Bhopal and the Department of physics and agrometeorology, Jawaharlal Nehru Krishi Vishwa Vidyalaya, Jabalpur, M.P. The district wise reported crop yield data were collected from Commissioner, Land Records, Gwalior, M.P. Weather indices were generated
Table 1: Geographical Locations of districts

\begin{tabular}{llll}
\hline Districts & $\begin{array}{l}\text { Latitude } \\
\left({ }^{\circ} \mathrm{N}\right)\end{array}$ & $\begin{array}{l}\text { Longitude } \\
\left({ }^{\circ} \mathrm{E}\right)\end{array}$ & $\begin{array}{l}\text { Altitude } \\
(\mathbf{M})\end{array}$ \\
\hline Balaghat & $21^{\circ} 8$ & $80^{\circ} 18$ & 288 \\
Jabalpur & $22^{\circ} 08$ & $79^{\circ} 53$ & 411 \\
Mandla & $22^{\circ} 59$ & $80^{\circ} 37$ & 445 \\
Narsinghpur & $22^{\circ} 91$ & $79^{\circ} 10$ & 347 \\
Seoni & $22^{\circ} 08$ & $79^{\circ} 53$ & 670 \\
Shahdol & $23^{\circ} 62$ & $81^{\circ} 42$ & 464 \\
Sidhi & $24^{\circ} 4$ & $81^{\circ} 9$ & 286 \\
\hline
\end{tabular}

*Note: - Five years average from 2003-04 to 2007-08 Source: Commissioner Land Records, Gwalior

using weekly cumulative value for rainfall and weekly average value of the other weather parameters as suggested by Ghosh et. al. (2014). After this the weekly data for all the weather variables selected weeks from sowing to post flowering $\left(44^{\text {th }}-12^{\text {th }}\right.$ standard meteorological week for wheat; $27^{\text {th }}-34^{\text {th }}$ week for rice) were used for developing models with crop yield data. The model were developed following methodology described by Ghosh et. al., (2014) as given below;

$$
Y=A_{0}+\sum_{i=1}^{p} \sum_{j=0}^{1} a_{i j} Z_{i j}+\sum_{i \neq i^{\prime}=1}^{p} \sum_{j=0}^{1} a_{i i}{ }^{\prime} Z^{\prime} Z_{i{ }^{\prime} j}+c T+e
$$

where

$$
Z_{i j}=\sum_{w=1}^{m} r_{i w}^{j} X_{i w} \quad \text { and } \quad Z_{i i{ }^{\prime} j}=\sum_{w=1}^{m} r_{i i^{\prime} w}^{j} X_{i w} X_{i^{\prime} w}
$$

These notations have their usual meaning as given by Ghosh et. al., (2014). Test criteria were used for analyzing 
Table 2: Yield forecast model for rice and wheat at pre-harvest stage in different districts of eastern Madhya Pradesh.

\begin{tabular}{lllc}
\hline Districts & $\begin{array}{l}\text { Normal yield } \\
\left(\mathrm{kg} \mathrm{ha}^{-1}\right)\end{array}$ & Regression Equation & $\mathrm{R}^{2}$ \\
\hline
\end{tabular}

\section{Rice yield models at pre-harvest stage $\left(27-34^{\text {th }}\right.$ week $)$}

$\begin{array}{llll}\text { Balaghat } & 1334 & \mathrm{Y}=2134+\mathrm{Z} 241 * 0.51 & 0.59 \\ \text { Jabalpur } & 889 & \mathrm{Y}=-652 .+\mathrm{Z} 50 *-2.65+\mathrm{Z} 51 * 21.11+\mathrm{Z} 230 * 0.007+\mathrm{T} * 21.64 & 0.78 \\ \text { Mandla } & 799 & \mathrm{Y}=4175+\mathrm{Z} 141 * 2.54+\mathrm{Z} 241 * 1.30 & 0.42 \\ \text { Narsinghpur } & 1248 & \mathrm{Y}=349+\mathrm{Z} 51 * 10.95+\mathrm{Z} 130 * 0.03+\mathrm{Z} 450 *-0.01 & 0.53 \\ \text { Seoni } & 1237 & \mathrm{Y}=867+\mathrm{Z} 451 * 0.02+\mathrm{T} * 12.06 & 0.65 \\ \text { Shahdol } & 1000 & \mathrm{Y}=3249+\mathrm{Z} 20^{*}-42.11+\mathrm{Z} 21 *-153.46+\mathrm{Z} 41 * 23.65 & 0.65 \\ \text { Sidhi } & 724 & \mathrm{Y}=291.15+\mathrm{Z} 51 * 0.88+\mathrm{T} * 13.44 & 0.54\end{array}$

Wheat yield models at pre-harvest stage $\left(44-12^{\text {th }}\right.$ week $)$

\begin{tabular}{llll} 
Balaghat & 914 & $\mathrm{Y}=-911+\mathrm{Z} 11 * 36.18+\mathrm{Z} 451 * 0.09+\mathrm{T} * 14.66$ & 0.60 \\
Jabalpur & 1499 & $\mathrm{Y}=-3122+\mathrm{Z} 11 * 116.09+\mathrm{T} * 59.47$ & 0.92 \\
Mandla & 895 & $\mathrm{Y}=1543+\mathrm{Z} 11 * 62.02+\mathrm{Z} 451 * 7.00+\mathrm{Z} 340 * 0.02+\mathrm{Z} 350^{*}-0.02$ & 0.67 \\
Narsinghpur & 2513 & $\mathrm{Y}=-3879+\mathrm{Z} 231 * 0.67+\mathrm{Z} 241 * 1.31+\mathrm{T} * 69.19$ & 0.78 \\
Seoni & 938 & $\mathrm{Y}=831+\mathrm{Z} 241 * 0.30+\mathrm{T} * 18.21$ & 0.63 \\
Shahdol & 927 & $\mathrm{Y}=949+\mathrm{Z} 231 * 0.89+\mathrm{Z} 450 *-0.008+\mathrm{T} * 6.93$ & 0.74 \\
Sidhi & 1001 & $\mathrm{Y}=346.05+\mathrm{Z} 40 *-2.53+\mathrm{Z} 51 * 15.64+\mathrm{T} * 13.91$ & 0.60 \\
\hline
\end{tabular}

error deviation between predicted $(\mathrm{P})$ and reported grain yield $(\mathrm{O})$. This was calculated using relative deviation $(\mathrm{RD})$ according to Baier and Robertson, (1967) as:

$R D=\left[\frac{(\text { Estimated yield }(\mathrm{P})-\text { Real yield }(\mathrm{O})}{\text { Real yield }(\mathrm{O})}\right] \times 100$

If $\mathrm{RD}$ is less, then the error will be less with less deviation suggesting a good model, or vice-versa.

\section{RESULTS AND DISCUSSION}

The forecast model developed for rice crop at preharvest stage had $\mathrm{R}^{2}$ values in a range of 0.4 to 0.78 (Table 2). It was less for Balaghat, Mandla, Narsinghpur and Sidhi districts as compared to Jabalpur, Seoni and Shahdol districts, where crop management practices apart from weather parameters also play a role in rice production. The relative deviation (RD) between predicted and reported yields for years 2010 and 2011 (Table 3) was positive in Mandla district and negative in Balaghat, Jabalpur, Seoni, and Sidhi districts. Overall validation suggest error per cent was less than 15 per cent in both the years. As model is purely weather based, excess rainfall in 2010 followed by low rainfall in 2011 along with more dry weeks situation that could be the reason for yield variation, as similar findings was also observed by Rajegowda et. al. (2014).
The forecast model equations developed for wheat crop at pre-harvest stage had $\mathrm{R}^{2}$ in a range of 0.6 to 0.92 at different locations (Table 2). Some districts with less $\mathrm{R}^{2}$ value suggested other factors like crop management practices, varietal potential, or soil types that may influences crop yield beside weather parameters. The relative deviation between (RD) predicted and reported yields for year 2010 and 2011 (Table 3) was positive in Mandla, Narsinghpur and Shahdol districts in both the years while it was negative in one year and positive in other year in districts Balaghat, Jabalpur, Seoni and Sidhi districts. Overall, the deviations were less than 15 per cent in both the years. These deviation with different trends may be due to the presence of climatic aberrations like heat wave at grain formation stage, unseasonal rains by mid- March or hailstorm that may influence reported yield. Adverse impact of temperature on wheat yield was reported by Lobell et. al. (2012). This condition may be prevalent in eastern M.P due to sowing of late-maturing rice varieties during kharif season, which delay sowing time of wheat and it matures by the end of March thereby coincide with high temperature phase. However, these variations with different trends suggest further refinement in the model equations

\section{CONCLUSION}

Rice and wheat yield forecast model equations during 
Table 3: Relative deviation (RD) between reported and forecasted yield of rice and wheat in different districts for 2010 and 2011

\begin{tabular}{|c|c|c|c|c|c|c|}
\hline \multirow[t]{2}{*}{ Districts } & \multicolumn{3}{|c|}{ Grain yield $2010\left(\mathrm{~kg} \mathrm{ha}^{-1}\right)$} & \multicolumn{3}{|c|}{ Grain yield $2011\left(\mathrm{~kg} \mathrm{ha}^{-1}\right)$} \\
\hline & $\begin{array}{c}\text { Reported } \\
\left(\mathrm{kg} \mathrm{ha}^{-1}\right)\end{array}$ & $\begin{array}{c}\text { Forecasted } \\
\left(\mathrm{kg} \mathrm{ha}^{-1}\right)\end{array}$ & $\mathrm{RD}(\%)$ & $\begin{array}{c}\text { Reported } \\
\left(\mathrm{kg} \mathrm{ha}^{-1}\right)\end{array}$ & $\begin{array}{c}\text { Forecasted } \\
\left(\mathrm{kg} \mathrm{ha}^{-1}\right)\end{array}$ & $\mathrm{RD}(\%)$ \\
\hline \multicolumn{7}{|c|}{ Rice } \\
\hline Balaghat & 1499 & 1447 & -3.58 & 1426 & 1313 & -8.59 \\
\hline Jabalpur & 1202 & 1093 & -9.96 & 1357 & 1232 & -10.08 \\
\hline Mandla & 964 & 973 & 0.95 & 1102 & 990 & 11.3 \\
\hline Narsinghpur & 1634 & 1471 & -11.06 & 1403 & 1296 & 8.19 \\
\hline Seoni & 1392 & 1211 & -14.85 & 1353 & 1189 & -13.70 \\
\hline Shahdol & 1938 & 1686 & -14.90 & 1346 & 1399 & 3.80 \\
\hline Sidhi & 922 & 848 & -8.64 & 1002 & 872 & -14.94 \\
\hline \multicolumn{7}{|c|}{ Wheat } \\
\hline Balaghat & 1301 & 1146 & -13.50 & 1188 & 1225 & 3.01 \\
\hline Jabalpur & 2430 & 2468 & 1.55 & 2741 & 2739 & -0.04 \\
\hline Mandla & 992 & 1089 & 8.90 & 1012 & 1176 & 13.98 \\
\hline Narsinghpur & 4144 & 4034 & 2.71 & 4144 & 3697 & 12.08 \\
\hline Seoni & 957 & 973 & 1.69 & 1149 & 1117 & -2.84 \\
\hline Shahdol & 706 & 824 & 14.32 & 914 & 903 & 1.197 \\
\hline Sidhi & 922 & 836 & 10.22 & 1103 & 986 & -11.81 \\
\hline
\end{tabular}

pre-harvest stage were generated for a 30 years of datasets, and validated for years 2010 and 2011. Relative deviation was both over- and under-estimated for both the crops with similar and different trends of deviation. The deviation between reported and forecasted grain yield was less than 15 per cent hence, it need further refinement to reduce it to 10 percent. However, these equations mayhelp us to estimate rice and wheat production at pre-harvest stage of the selected districts of eastern Madhya Pradesh.

\section{ACKNOWLEDGEMENT}

The authors are grateful to India Meteorological Department, Ministry of Earth Sciences, New Delhi in providing financial assistance under Forecasting Agricultural Output using Space, Agrometeorology and Land based observations (FASAL) project to complete this work successfully.

\section{REFERENCES}

Baier, W. and Roberson, G. W. (1967). Estimating yield components of wheat from calculated soil moisture. Candian J. Plant Sci., 47: 617-630.
Ghosh, K., Balasubramanian, R., Bandopadhyay, S., Chattopadhyay, N.,Singh, K.K. and Rathore, L.S. (2014). Development of crop yield forecast models under FASAL-a case study of $k$ hairf rice in West Bengal. J. Agrometeorol., 16(1): 1-8.

Lobell, D.B. Sibley, A. and Ortiz-Monasterio, J.I. (2012). Extreme heat effects on wheat senescence in India. Nature Climate Change, 2: 186-189.

NPCC (2007). Network Project on Climate change. Final Report. Central Research Institute for Dryland Agriculture, Hyderabad.

Rajegowda, M. B., Soumya, D.G., Padmashri, H.S., Janardhana Gowda, N. A. and Nagesha, L.(2014). Ragiand groundnut yield forecasting in Karnataka - statistical model. $J$. Agrometeorol., 16(2): 203-206.

Yoshida, S. and Parao, F.T. (1979). Climate and rice. Intl. Rice Research Institute, LosBanos, Philippines(Cf. $A d v$. Agron. 28:301-359). 